\title{
The Media, Implementation of the Nigerian National Communication Policy, and Citizens' Participation in Development
}

\author{
Joshua Suleiman \\ Department of Mass Communication, \\ Babcock University, Ogun State, Nigeria
}

Doi:10.19044/esj.2018.v14n26p193 URL:http://dx.doi.org/10.19044/esj.2018.v14n26p193

\begin{abstract}
This study examined some of the objectives, functions and implementation strategies of the Nigerian National Communication policy for the print and the broadcast media. The general aim of the policy was the development of the nation. The purpose of this study was to find out whether or not the implementation strategies of the policies had been effected by government, and the extent to which the media had performed the functions that the communication policy assigned to them, to bring about development, particularly in the rural communities. This study underscored the capability of the media to facilitate the economic empowerment and improvement in the quality of life of the rural people. The study revealed that both government and media needed to do more than necessary, and work collaboratively to reduce the growing poverty in Nigeria's rural communities. This study adopted a conceptual framework and relied on secondary and tertiary sources.
\end{abstract}

Keywords. Communication Policy, Development, Media, Citizens' Participation

\section{Introduction}

Information is recognized as a component of empowerment and participation in development. The traditional role of the media to facilitate the exchange of information, educate and enlighten the citizens has long been identified as very crucial. The media also function to keep the citizens abreast of developments, expose them to new ideas, and serve as a veritable platform for them to contribute to the quality of government's policy, and to the good governance of the nation. Good governance implies development in every aspect of life of the citizens. It represents the norms, values and rules through which public affairs are managed in a transparent, participatory, inclusive and responsive manner (Ogundele, 2018). Good governance is key to the 
development and progress of any country. The purpose of development is improvement in the quality of lives of the people - their social and material wellbeing (Amodu, 2008). It also means continued improvement in the human and economic well being of the people from one stage to another (Chambers, 1997).

The importance of communication in achieving the goals of development of a nation inspired the formulation of the Nigerian Mass Communication Policy (NMCP) in 1987. The policy was reviewed in 2004. The reviewed version was approved and adopted in 2010 as the Nigerian National Communication Policy (NNCP). The overarching aim of the policy is to drive the socio-political, economic and cultural development of the country through galvanizing mass participation in government's programmes, processes, and expanding opportunities for the citizens' self-expression and actualization. To this extent, the NNCP provides a framework for the growth, development, regulation and functioning of all available communication systems in the country (NNCP, p.4).

The NNCP was a direct consequence of the findings by the United Nations Educational, Scientific and Cultural Organisation (UNESCO) in 1972 that communication could play a prominent role in a nation's development. The Organization was of the view that if nations could develop policies on communication, they would assist them in their social, economic, political, educational and cultural development agendas. Thus the Organisation defined communication policies as a set of principles and norms established to guide the behavior of communication systems. According to UNESCO, the orientation of communication policies is fundamental and long-range but with operational implications of short-range significance. These policies are defined in line with the society's approach to communication (Michael and Kayode, 2012, p.13.) and they are to activate the development process particularly in developing countries such as Nigeria. With respect to the Nigerian situation, communication policy would be vital to stimulating the participation of the rural populations in development programmes. The policy would install a functional system that could mobilise the citizens to participate, exchange knowledge and ideas, and coordinate development efforts.

Nigeria is among African countries that are still struggling to reach the desired level of development. The nation is characterized by one of the world's lowest human development index as a result of her poor per capital income, large and fast population growth rate, import-oriented economy and high unemployment (UNDP Report, 2016). Nigeria has the world's highest population living in extreme poverty - 87 million people (Daily Post, 2018), and the country lacks basic welfare facilities. According to Thirlwall (2003) these are features of a poor country. In addition, the nation's inadequate infrastructure, official corruption, political and economic instability, 
continuing insecurity, and unavailability of sufficient power supply have contributed to the problem of development in the country and other third world countries Diso cited in Harande (2010). The high poverty level in the country continues to worry almost everyone despite the nation's abundant human and mineral resources.

Against this backdrop Uwom and Alao (2013) called for the formulation of a national communication policy to meet the developmental needs and aspirations of the citizens of the country. These needs include but not limited to, improved quality of health, reduced poverty level, increased life span of the citizens, greater opportunity and access to knowledge acquisition, high income, and high standard of living. Uwom and Alao (2013) asserted that Nigeria did not have a national communication policy and recommended that:

An official national communication policy should

be formulated and duly approved by the government (Uwom and Alao, 2013).

The above opinion however, is at variance with Adekoya and Ajilore (2012) who stated that Nigeria had a near perfect communication policy but with a fundamental problem of its implementation. The authors attributed this problem of implementation to certain economic and ethical factors such as poverty, corruption and unwholesome practices of media practitioners.

It is necessary to point out that there is little or no

problem in our national communication policy and the

roles it has assigned to various media towards the

achievement of national development, the problem lies

in the execution of these roles (Adekoya and Ajilore, 2012).

Pate, Akinfeleye, and Oso (2016) as reported in The Punch Newspaper, acknowledged the existence of Nigeria's communication policy but expressed concern about its poor implementation as a result of pervasive corruption, difficult operational climate, urban-centered journalism, weakening government investments, and failing public media sector. They called for the review of the national communication policy to accommodate an implementation strategy that should simultaneously take place at the federal, state and local levels, while re-stating the need to de-emphasize urban journalism. Pate, Akinfeleye, and Oso (2016) stressed that the Nigerian government should identify organs through which the national communication policy would be implemented, as well carry out research and measurement of its effectiveness, and involve stakeholders such as the private sector, civil society and political parties in the review process.

The view of Johnson and Alao (2013) affirmed the positions of Adekoya and Ajilore (2012), and Pate, Akinfeleye and Oso (2016) to the 
extent that Nigeria has a communication policy. Johnson and Alao (2013) however asserted that the policy was incoherent.

There is no coherent communication policy in Nigeria;

it is made up of litany of constitutional and institutional

(professional) frameworks (Johnson and Alao, 2013.)

The authors recommended a coherent document that harnessed the totality of the existing extant communication laws guiding the practice of the various professional communication bodies in Nigeria. They were of the view that if the national communication policy was coherent, and its formulation and implementation strategies incorporated professionals and scholars in mass communication, the document would be implementable. This would indicate that an implementable policy is one that is contained in one document. But a communication policy does not have to be coherent or be contained in one document for it to be robust, workable or implementable.

Communication policy may be dispersed through various institutions and institutional norms or may be centralized or concentrated (Michael and Kayode, 2014,p.13).

The foregoing views affirmed the existence of a communication policy in Nigeria, contrary to the position of Uwom and Alao (2013). The unifying thread of opinion among the studies cited above is that the Nigerian communication policy is far from being implemented, and the blame for its non-implementation was placed at the door of the government. (Johnson and Alao, (2013) stated that the policy was not workable or implementable because mass communication professionals and scholars in the academia were not part of it, and that its development did not factor in the role of the various mass communication bodies and institutions that regulate the practice of communication in the country.

Adekoya and Ajilore, (2012) affirmed the view that implementation was the problem with Nigeria's communication policy, and averred that both the government and the media must demonstrate the will and strength of purpose to implement it because it was capable of achieving its goal of national development. Pate, Akinfeleye and Oso (2016) believed that very little visible efforts had been made by government to implement the communication policy. This current study therefore examines the extent to which the Nigerian National Communication Policy has been implemented in line with its set out objectives and implementation strategies for the print and broadcast media to perform their functions.

\section{Theoretical framework}

This study adopts the development media theory by Dennis McQuail (1987). The theory states that the mass media and communication have a 
facilitating role to play in the development process of developing nations because of its capacity to influence opinion and behavior (Anaeto and Anaeto, 2010). The media can play this role by promoting national development programmes which developing nations need for sustainable development, and by being an ally of government in development (Moemeka, 2012). According to Folarin (1998) some of the principles guiding the theory include that: the media must accept and carry out positive development task in line with nationally established policy without prejudice to their traditional functions; the media should accept and help in carrying out special development task of national integration, socio-economic modernization, promotion of literacy and cultural creativity; the media should give priority in their content to the national macro culture, regional cultures and local cultures. The relevance of the theory is that it spells out the activities of the media in development. The theory perceives the media as key players in a nation's development agenda, and explains how the media can be used to promote development in developing nations. Naomi (1995) asserted that development involved not only economic growth, but also the notion of equitable distribution, provision of health care, education, housing and other essential services with a view to improving the individual and collective quality of life (Naomi, 1995).

According to McQuail (2000), mass media act as agents of development by sending out information on technical knowledge, encouraging individual change, exercising voting right, aiding literacy, education, population control, and good quality of health. The media play this role by serving as agents of mobilisation, which Rosengren (2000) said was meant to provide formal, educationally-oriented socialization, conserve existing power structures, and support on-going process of change necessary for any modern society. The radio and television are relevant to this theory.

Democratic participant theory by McQuail (2000) is also used for this study. The theory advocates easy access to media for all who are potential users or consumers of media. McQuail (2000) in this theory supported the right of the people to relevant information, the right to exchange of opinions, and the use of the new means of communication for interaction and social action in community, interest group, and sub-culture. The theory serves the need of the local or small population setting. The radio, particularly community radio, fits into the structure of this theory.

The third theory is the participatory model by Paulo Freire (1983). The model emphasises the importance of cultural identity of local communities and democratization and participation at all tiers of governance - national, state, local and individual. It stresses the right of all people to express their views. According to Anaeto et al. (2008), 'Participation is necessary in order to share information, knowledge, commitment and a right attitude in development planning and implementation. But, it must be anchored on belief 
in the people's ability to contribute and participate actively in the task of transforming society. A participatory process involving people is therefore achievable through information sharing. According to Diouf:

Unless people themselves are the driving force of their

own development, no amount of investment or provision

of technology and inputs will bring about any lasting

improvements in their living standards (UNDP,1994,

p.1).

Communication can help the citizens become drivers of their own development. According to Greater Hume Shire Council (2015), communication is beneficial for the success of development project because:

Information is exchanged and decisions are understood, it assists in building a positive reputation, exercises community leadership, builds networks and collaboration, provides ample opportunities for feedback, strengthens and bonds relationships with stakeholders, generates community support because involvement makes for better decisions, helps to build resilience to adapt to changing circumstances, provides a platform of strength to manage crises, and improves membership morale. (Greater Hume Shire Council, 2015,p.7.)

\section{Communication policy}

There are many definitions of communication policy. UNESCO gave the first official definition of communication policy in 1978 (Michael and Kayode, 2014). Communication policy is a set of principles and norms established to guide the behavior of communication systems (UNESCO, 1978:8). This means that nations could have a body of rules that guides the operations of their communication organs such as radio, television, newspapers, information communication technology, and telecommunication. There are other definitions of communication policy by different scholars but all are unanimous that it is a sort of guide for the functioning of communication systems (Boafo, 1986 p.37).

Boafo (1986) explained that a national communication policy enunciates the goals, objectives, and functions of communication system and aims at aligning these with the overall socio-cultural, political and economic climate of the society. That is, communication policy is tailored to the specific circumstances, or situations, or history or ideology of a country. This definition is similar to that by Beltran cited in Viso and Ortis (2012:5) that:

Communication policy is an integrated, explicit and durable set of partial policies organized into a 
consistent body of behavior principles and norms for a

country's communication activities or processes.

This implies that it is government that directs how communication systems should function. However, international bodies such as UNESCO, European Union (EU) or African Union (AU) also can produce formulate communication policy (Michael and Kayode, 2014). This explained the background of the first definition of communication policy which was given by UNESCO in 1972 .

Braid et al., (1990) regarded communication policy as the guidelines on ownership, distribution and utilization of communication resources; the relationship between media, government and business; and the framework by which the present structure may be transformed so that they can support the goals of building a just and human society. This connects with the view of UNESCO that communication policy emanates from the political ideologies, social, economic and cultural conditions of a country, and from the values on which they are based. UNESCO added that communication policy strives to relate these conditions to the real needs for and prospective opportunities of communication. Sarikakis (2010) stated that communication policy is the general principles which guide decisions of authorities usually governments, about the duties of the mass media; issue of technical infrastructure; government media relationship; and technological development.

On the nature of communication policy Michael and Kayode (2014) opined that communication policy may be implicit or explicit, centralized or concentrated or dispersed through different institutions or bodies. The authors noted that while some countries had unwritten communication policies which were the sum total of various decisions taken at different times and levels, few other countries had explicit communication policies. The major purpose of a national communication policy is to set out a workable guideline by which a country's communication systems will operate in a coordinated and systematic way, for the good of society. It stipulates functions for the media in relation to the nation's development objectives.

\section{Nigerian National Communication Policy and the media}

The Nigerian National Communication Policy was formulated in 1987 during the military regime of President Ibrahim Badamasi Babangida, but it was adopted for national use in 1990 following its approval by the federal executive council. The demands of society's dynamism occasioned by changes in information communication technology and information management challenges warranted the review of the policy in September 2004. This exercise gave birth to the extant July 2010 Nigerian National Communication Policy (NNCP). The chapter one of the NNCP titled 'Communication for development' spells out the following policy objectives: 
Based on the foregoing consideration the National Communication Policy has the following objectives:

1. Positively affect the quality of life of the peoples of Nigeria.

2. Facilitate coordination and systematic enhancement of national communication strategies and activities to support development.

3. Promote participation in national dialogue on development issues by all citizens, consistent with the emerging democratic culture and national constitutional provisions.

4. Foster access to information and communication infrastructure and new technologies for all citizens.

5. Promote assessment, adaptation and adoption of technological and other communication innovations.

6. Preserve national culture identity, promote the national cultural patrimony and enhance the development of cultural and artistic capabilities and institutions for public communication.

7. Ensure timely, orderly and effective growth of information and communication institutions through professional standards setting, capacity building and human resource development.

8. Promote interchange of balanced information at community, national regional and international level.

9. Protect and promote the right and security of women, youth, children and the physically challenged.

10. Ensure repeal of all laws and statutes that impede the development and growth of independent media (NNCP, July 2010, p. 4).

The themes that run through the above objectives are improved quality of life, exchange of information, development, access to information and information infrastructure. The objectives suggest an ambition on the part of government to use available communication systems to drive the development of the nation and build a well-informed citizenry through dialogue on national issues and information exchange. Adekoya and Ajilore (2012) showed that communication targeted at giving the masses necessary information would enable them to participate fully in the development process; that a national communication policy can be implemented to bring about national development; that the media can serve as a vehicle for national mobilisation in support of policies and programmes aimed at improving the standard of living of Nigerians; and raising the people's level of consciousness. The NNCP specifies the following functions for the print media:

1. Promote the exchange of ideas and information through accurate and balanced reporting as well as informed and objective comments.

2. Protect the basic interest of the public and ensure quality independent journalism.

3. Uphold the principle of plurality of ownership and control. 
4. Prevent monopoly and concentration of media resources and infrastructure.

5. Improve feedback with readers through interactive technologies and practices.

6. Support the growth, development and utilisation of broadband multimedia and future emergent technologies.

7. Reflect the centrality of development efforts (NNCP, 2010, p.6).

The objectives of this policy and the functions assigned to the print media are in line with the development media theory, which states that the media must accept and carry out positive development task in line with nationally established policy without prejudice to their traditional functions. Therefore, the media must at all times ensure the development and progress of the country where they operate (Folarin, 1998). The media, because of their inherent qualities, should be a companion of government in development. Alao and Johnson (2013) underscored the importance of communication policy to address the imperfections of communication flow by providing a system of regulations that guide organisations, institutions and nations, and to fast track development. It is in recognition of these roles that the NNCP was established. The NNCP mandated the country's media to carry out their functions with the goal of aligning with government to bring about the development, progress and stability of the country. The NNCP adopted certain strategies to (a) positively affect the quality of life of the people, (b) Promote participation in national dialogue on development issues by all citizens, (c) Promote interchange of balanced information at community, national regional and international levels. Some of the strategies that the NNCP adopted to achieve this with the print media are that:

1. The state shall enact laws that promote access to information and the free and balanced flow of information, and ensure repeal of all laws impeding the free-flow of information.

2. The state shall provide incentives for the development of community and indigenous language newspaper and publication.

3. The print media industry shall be provided with incentives such as removal of import and excise duties on equipment, newsprint, ink and other production inputs.

4. The print media shall be encouraged to practice self-regulation through an independent media commission, which will administer a code of ethics prepared by professional media organisations. The commission, largely administered and supervised by media professionals; and governed by moral suasion, shall promote the observance of the code, as a means of holding the print media accountable to the public. 
5. The Nigeria Press Council (NPC) shall be strengthened and given the enabling environment to enforce external regulation and promote professionalism.

6. Regulatory bodies and workers unions in the print media shall strive for the protection and promote the welfare of workers.

7. Publishers shall provide their employees conditions of service that includes regular remuneration (NNCP 2010, pp..14-15).

This study focuses on strategies 1-4 above (NNCP 2010:14). The Nigerian National Communication Policy objective (1) for development is to positively affect the quality of life of the peoples of Nigeria (NNCP 2010:5). The peoples of Nigeria live in urban and rural areas across the country. To achieve this objective the print media are required to perform their duties in such a way as to:

1. promote the exchange of ideas and information through accurate and balanced reporting as well as informed and objective comments.

2. protect the basic interest of the public and ensure quality independent journalism

3. improve feedback with readers through interactive technology and practices (NNCP, 2010, p.6).

Repeal of restrictive laws: One of the strategies to promote exchange of ideas and information flow among the citizens, protect the basic interest of the public, and improve feedback with readers was to abrogate laws restricting freedom of information (NNCP 2010, p.21). A critical look at the current environment under which the media function reveals an atmosphere of freedom in line with the provision of the nation's 1979 Constitution that grants media freedom, and freedom of expression. The NNCP stated that the state shall enact laws that promote access to information and the free and balanced flow of information, and ensure repeal of all laws impeding the free-flow of information (NNCP 2010, p.14). The government has repealed laws that inhibited media freedom. Such laws include those dealing with circulation of newspaper decree 2 of 1966, offensive publication decree 35 of 1993, the official secret act, sections 50-52 of the criminal code on sedition and sections 373-379 of the criminal code on criminal defamation to mention a few. Ownership of media by citizens, groups and associations is now permitted.

The enactment of the Freedom of Information Act on May 28, 2011 by President Goodluck Jonathan was one the measures that the government took to increase accessibility to information held by public office holders, protect the interests of the public, and ensure quality independent journalism. The Act promotes transparency and accountability in government, and gives access to public records, and criminalises destruction of public records (Freedom House, 2011). Legalising freedom of information is part of strategy to empower people with information. It enables the citizens to hold their leaders 
accountable to the delivery of dividends of democracy, which include economic and social empowerment that could contribute to their development.

Self-regulation: The print media in consonance with the NNCP 2010 implementation strategies is allowed to practice self-regulation through an independent media commission. This independent body is the Nigerian Press Organisation (NPO). The NPO administers a code of ethics prepared by professional media organizations. The organization comprises media practitioners and government appointees with experience in communication. In 2017 the NPO banned all 'beat associations' in the country for reasons of unethical practices involving financial and material corruption. Members of the NPO such as the Nigeria Union of Journalists have a code of ethics that guides the conduct of their members in the performance of their functions. The NPO is the promoter of the observance of the code as a means of holding the print media accountable to the public.

Removal of import duties: However, the government is not known to have implemented the strategy that could have made print journalism management less expensive, increase and sustain the number of existing publications. The communication policy stated that the print media industry would be provided with incentives such as removal of import and excise duties on equipment, newsprint, ink and other production inputs. This concession is important to the effective functioning of the media considering the parlous state of the Nigerian economy under which the media function. The media require huge investment in their operations without which they become inefficient. Lack of incentives could predispose the media to pay lip service to objectivity and fairness.

The print media in the 70 s enjoyed low import duties on imported printing materials. Moreover, the Iwopin and Oku Ibuku paper mills in the country were able to partly meet the print media newspapers supply needs. Also in the past, government's subventions to the Federal Radio Corporation of Nigeria, and the Nigeria Television Authority were enough to keep those media organisations afloat. That ended by the 1990s with the downturn in the nation's economy. To address this, the military President, Ibrahim Badamasi Babangida introduced an economic policy called Structural Adjustment Programme (SAP) in 1996. The programme brought a lot of economic challenges to business organisations.

According to Ekwo (1996) SAP was an economic policy aimed at encouraging self-reliance and reduction of over dependence on government business. This forced most social institutions including the media to think of alternative survival strategy. It also made it difficult for media organisations to pay salaries of workers, produce or service available equipment and led to a myriad of other problems. Many newspapers and magazine shut down. The media had to devise several other means to generate revenue to perform their 
duties. This difficulty in sourcing the needed funds forced the media to consider first their commercial interest before the public interest Ekwo (1996). The high cost of doing business in Nigeria, high cost of imported materials such as newsprint and ink, and broadcast equipment, most of which are imported, became a disincentive for media owners and practitioners. The consequence of this was the shift of media attention to the political elite and big economic players and institutions in the country as sources of news because they have the financial muscles to buy news slots and advertising spaces. It shifted focus from reporting on rural communities and their people, distanced them from participating in national dialogue, and made it difficult for their views and opinions to be heard and counted.

The media on the other hand shirk in their responsibility to ensure the promotion of the welfare of their employees, to get them motivated to perform their duties in pursuance of the NNCP's goal of improving the quality of life of the people through quality reporting and exchange of information and ideas. The Nigerian journalist is among the poorest paid in the world. The financial challenge of the media is further compounded by the inability of majority of Nigerians, particularly those in the rural areas, to pay for media service. In addition, advertisers hardly pay for the cost of advertisement, thus making it difficulty for revenue generation from advertising, which is the major source of media income. In September 2018 the National Broadcasting Commission disclosed that some broadcast stations were owing licensing renewal fees to the tune of N4.3bn (The Punch, 2018). The media owners attributed this debt to the bad shape of the Nigerian economy, and that it accounted for the nonpayment of salaries of their employees. This is partly responsible for the corruption in the media, and the lack of authenticity in some of their reporting.

A study by Omojola (2010) reported that the media is corrupt and would fail to criticize government if it was given advertisement insertions or commercials. He noted that as long as the media continued to place commercial interest above public interest, corruption would remain and the citizens would wallow in poverty. This practice by the media jeopardizes authentic reporting of information about government programmes that could enable informed feedback from the citizens. Allotting more time to government news could result in little or no time for reporting on poverty reduction, and the worsening condition of rural people. It is on this ground that Adekoya and Kayode (2012) asserted that if government and journalists played their roles as stipulated in the NNCP implementation strategies, there would be improved development in every sphere of life of the Nigerian citizen.

The implementation strategies mapped out for the broadcast media to enable them contribute to national development through information dissemination for enlightenment, education, and participation in national development included those for commercial, public and community 
broadcasting. The general implementation strategies for the broadcast media include to:

1. Recognize and promote three tiers of broadcasting, public, private/commercial and community.

2. Support the right of broadcasters to access information held by public/government and corporate organizations.

3. Establish a Production Fund to encourage local independent productions.

4. Promote collaboration between BON and the National Bureau of Statistics to make available on an annual basis, statistical information on broadcasting, which includes ownership of radio and television sets etc. in the country.

5. Ensure review and update of the broadcasting code to achieve congruence with the provisions of this policy.

Increase in licensing of broadcasters: The first implementation strategy for the broadcast media (NNCP 2010, p.15) is to "recognize and promote three tiers of broadcasting, public, private/commercial and community". This resulted in the increase of licenses to commercial and community broadcasters, and expansion of public broadcasting network. As at 2012 the National Broadcasting Commission (NBC) licensed 402 operational broadcasters of which 123 were privately owned. There were also 233 radio and television stations owned by the federal and state governments, as well as 46 cable stations. This was not the situation before 1990 when the NNCP was approved. The number of government owned broadcasting stations was far lower compared to the current figure.

Review of broadcasting code: The National Broadcasting Commission NBC in line with the 2010 NNCP strategy (5), which is to "ensure review and update of the broadcasting code to achieve congruence with the provisions of this policy" (NNCP 2010:15). The NBC has continued to review the broadcasting code in line with the goal of meeting the communication and information needs of the media to facilitate the performance of their functions by producing programmes that educate and enlighten the citizens with ideas and information necessary for their development. The call for public input into the review of the $5^{\text {th }}$ edition was made in July 2015. The code is a body of the principles, rules and regulations guiding the practices and operations of the broadcast industry. The code ensures that broadcast programmes are $70 \%$ local content. This is to engender cultural revival and identification. Media stakeholders produced the first edition of the code in 1994, under the supervision of the NBC.

The implementation strategy (3) regarding the "establishment of Production Fund for local independent production of programmes to take into account the specific needs of the states or zones where the media operate has 
not been implemented" (NNCP 2010:15), would have allowed the broadcast media to access funds to meet their production needs.

The 2010 NNCP also outlined specific implementation strategies for the public, commercial and community broadcasting. The ones considered relevant to this study are:

\section{Public broadcasting}

1. Government controlled broadcasters shall be transformed into public service broadcasters, accountable to the public through legislature.

2. Their funding shall be provided through a combination of the following dedicated funding: direct from the legislature, radio/television set ownership fees and limited advertisement.

\section{Commercial broadcasting}

1. They shall derive their funding from commercial activities.

\section{Community broadcasting}

1. Community broadcasting shall be promoted as direct from decentralized state/government broadcasting.
(a) Community development associations
(b) Other civil society groups
(c) Cooperative societies
(d) Educational communities

2. The ownership, management and programming of community broadcast media shall be participatory and representative of the diversity of their communities.

3. They shall derive funding from any of a combinations of the following:

(a) Contributions of community members.

(b) Grants/donations.

(c) Sponsorships.

(d) Limited advertisements.

(e) Spot announcements.

(f) A community broadcasting trust fund (NNCP, 2010, P.14-16).

Government controlled broadcasters have remained mouthpiece of government activities. They are purely elitist (Akinfeleye, 2016) and urban centered. Very little reporting of rural communities is done by government controlled and owned media. Yet because of their large network, the Nigeria Television Authority (NTA) has the capacity to mobilse the rural people for development. In the 1980s, the NTA prime time programme called Newsline anchored by Frank Olize, and presented by Patrick Oke and Yinka Craig brought the pitiable conditions of the rural communities to national glare for discussion. Apart from highlighting the cultures of the rural communities, it 
drew the attention of government to the poverty of the rural people. The local people had until then no access to the media to express their opinions and feelings on how they thought development could be brought to their communities, and the economic impact it would have on their quality of life. The Newsline as a programme was a huge success. It enjoyed massive viewership by both the elite and non-elite population in urban cities. At the time, the local people had no means of viewing the programme because they had no access to the media. The programme elevated the story of 'the common man' from the pedestal to the top level of national discourse.

Establishment of community radio: To encourage exchange of information, and bring development closer to the people, especially those in rural areas, the federal government in 2006 set up a committee chaired by renowned scholar Alfred Opubor to develop a policy framework for the establishment of community radio stations for Nigeria (Ajibade and Alabi 2017). As at 2016, only 3 of the 17 licensed community radios were functioning (The Punch Newspaper, 2016). The reason for the small number was due to the cost of establishing community radio. The government requires a closer examination of the strategies outlined in the NNCP for the establishment of community radio to make it cheaper for communities to own one. Without this, efforts by government to partner the media for development in the rural areas will yield no positive result. Yet community radio is closer to the people and they can relate well with it and participate in creating programmes that can empower the community with the right information.

Nigeria's first community radio station, Lavun 95.5 FM Community Radio in Niger State began broadcasting in September of 2015. The radio station was supported by the World Bank's Fadama II and III projects. The radio gives voice to the people in community mobilization and decision making, which is one of the goals of the NNCP. The radio broadcasts programmes that create awareness on agricultural value chain, health practices, cultural revival, promotion of peace and unity among the communities in the local government area and the state generally. According to Amina Jibrin a member of the Jipan Women Farmers' Community Association:

We are benefiting from the radio station in the area of shea butter processing and value addition. We rely on the radio for information on how to market our shea butter products that we produce in the community" (The World Bank, 2015).

Adekoya and Ajilore (2012) noted that meeting the national development goal of the NNCP would require that government, private media owners, independent producers and other communication agencies endeavor to create more programmes that are national and development oriented with 
particular interest in the plight of the nation's citizens. The authors asserted that government should empower the rural people towards the ownership of their own media of mass communication to facilitate effective participation in the nation's development programme. The Niger State Lavun community radio through its agriculture programme is a direct response to this, and the community is already excited about it because it gives them the right and appropriate information to boost their Shea butter sale and improve their income level. This demonstrates that collaboration between government and the media can improve the economy of the rural people. The people are able to express their views and share ideas and skills through participation in the programmes while listening in. This is the sense in which community radio can bring about improved level of education and awareness that results in human capacity development.

\section{Citizens' participation in development}

Participation has been defined in different contexts. In modern times participation is equivalent to 'sharing' (Kaler, 1999). But Gram (1993) and Wolfe (1985) both cited in Mohammad (2010) described participation in relation to the concept of empowerment. Participation may mean nothing without empowerment. Citizens' participation is the process of empowerment of the deprived and marginalized (Samad, 2002). Participation also means partnership. Cohen \& Uphoff (1980) described participation in respect to development projects as people's involvement in decision making processes, in implementing programmes, sharing in the benefits of development programmes and involvement in efforts to evaluate those programmes. According to Khan (1998) cited in Mohammad (2010) participation is:

a) an organized effort to increase control over resources and regulative institutions;

b) people's involvement in decision-making, implementation, benefitsharing and in evaluation of programs;

c) people's capacity to take initiative in development, to become "subjects" rather than "objects" of their own destiny. It is to make "ordinary people" responsible for their own well-being;

d) a reversal of role playing: people as the primary actors while government agencies "participate" in people's activities.

The idea of people's involvement in decision-making, implementation, benefit sharing and in evaluation of programs is fundamental to the development of the rural communities in Nigeria.

\section{Development}

Development is a multidimensional process, involving major changes in social structures, acceleration of economic growth, reduction of inequality 
and eradication of absolute poverty. This process deals with the economic advancement, human dignity, self-reliance, security, justice and equity of the citizens of a nation (Nazneen, 2004). Development in the context of this study is about the improved quality of life of the people in the rural areas through proper involvement of the people in decision-making, information sharing, benefit sharing, and implementation of development projects. Since a country's economic development is related to its human development in aspects such as health, education and employment, government of each country, to meet the specific needs of its rural people, would implement development programmes that can positively impact the lives of these people. Participation in these programmes becomes an indispensable ingredient of development.

There is no successfully implemented development programme without the participation of those for whom the development is meant to impact. The rural people themselves should be allowed opportunity to jointly brainstorm and make decisions about development plans (Scrampical, 2007 cited in Adekoya and Ajilore, 2007). This participation in decision-making and planning process empowers everyone to ownership of development programmes, projects and their sustainability. Any meaningful economic development programme for the rural people therefore requires the effective involvement of the people.

\section{The media and citizens participation in development programme}

The media have become a critical social institution as a result of the crucial role they perform in society. Lasswell (1948) cited in Hanson and Max (1996) was the first scholar to discuss the roles, which the mass media perform in contemporary democratic society. Lasswell identified three functions of the media in the modern world: surveillance of the environment, correlation of the parts of the society in responding to the environment and transmission of social heritage. Inuwa (2007) added that the media also entertain and help in the formation of attitude by establishing values for society, thereby building a climate of change in the nation. These roles lie in the capability of the media to teach, manipulate, sensitize and mobilise through the dissemination of information (Uchanya, as cited by Nwabueze, 2005). This information confers on people the power of participation. The Northern Nigeria under the provincial and native authority administration, produced films to activate agricultural production, especially after the collapse of the textile industries in the United Kingdom due to global cotton drought (Paden, 1986). The Northern Nigeria Film Unit produced films on cotton production, raised awareness and increased cotton yield among local farmers that contributed to revitalizing the British textile industries. The Ahmadu Bello University in Zaria, northern Nigeria, used television programmes to stimulate interest in agriculture. Its 
National Agricultural Extension and Research Liaison Services used local languages in their radio dramas, interviews, and panel discussions programmes to educate its listener, and increase its listenership, and consequently recorded high impact on their target audience.

Anaeto et al (2008) cited in Adekoya and Ajilore (2012) affirmed that participation was necessary in order to share information and knowledge and a right attitude in the development process. The view supported Gadzekpo (1997 p. 34) as cited in Uwom and Alao (2013). The author drew a correlation between communication and development needs of peoples of a nation. This implies that every development programme that takes people as ordinary recipients, rather than the actual creators of change and progress, has little or no chance of success. The media in this regard are agents that can facilitate progress by communicating the right message, producing the needed educational and enlightenment programmes to help improve the quality of life of the citizens, and in support of government's development efforts. This point of the media as facilitators of development was well articulated by McQuail's (2000) and Freire (1978).

People's participation in development programmes seems to be heavily determined by the socio-economic factors in which they live. This should not be the case. But this situation accounts for why socially poor, disadvantaged community and minorities are seldom asked for participation in government driven programmes and projects. It also explains why the media rarely focus their coverage on the rural areas and their poor people. The media hardly seek the views of the rural people about their economic and social plights, or reflect their views in the national media discourse. Even the state media organisations in Nigeria are hardly accessible to the rural people. They therefore have no means of knowing what is going on around them, and how they can share in the benefits of any development programme, or contribute to its success. At a time that national development has become very challenging, particularly in rural areas where there are no social and economic infrastructures to help improve the quality of life of the people, poverty has become their permanent feature. They are not able to move their farm products to the urban markets for sale to generate income for their welfare (Nwanne, 2013). This also explains why the rural people remain poor. Yet the media have been identified as a formidable force that can empower the rural people economically by offering information on how the people can market their products, and the different marketing opportunities available for their products. The Lavum community radio in Nigeria has demonstrated how the rural people can be economically empowered through local programmes that teach them the economic benefits of Shea butter production and how it can be marketed for good source of income.

Moemeke (1989) observed that the media have the potential to aid 
community development not just by transmitting information about how things can be done better, but by using available facilities, exchanging information that helps to solve problems, generating empathy, raising aspiration, teaching new skills, and encouraging local participation in development activities, such new cassava planting technology that can result in high and healthy yields, or a new technology that controls pests from destroying farm crops. The media therefore have the capability to encourage productivity in agriculture by encouraging the rural population to adopt modem methods of farming. Media content can serve as a source of psychological upliftment of the rural people by encouraging them to attain their highest potential. Such encouragement is needed for development and the media are eminently qualified to address such an issue (Nwanne, 2013).

Government must however retool its strategies of implementing the national communication policy to ensure that the media are empowered financially, and given more incentives that can enable them expand their coverage of the rural areas and produce adequate educative programmes targeted at exposing the rural population to development programmes, and eliciting their views on subjects of crucial importance to them. Through such enlightenment programmes they can hold their government accountable.

\section{Conclusion}

Nigeria has a comprehensive communication policy. This policy is being implemented though much is still required for it to drive the development of the country and the empowerment of the citizens. The media have also shown that local programming facilitated economic growth and empowerment of people in rural areas in northern part of Nigeria. Lack of infrastructure is a major problem that the rural people face in Nigeria but with adequate access to the media, they can improve the quality of their life.

\section{Recommendation}

There is a need for the Nigerian Communication Policy to be reviewed regularly as the policy itself provides. While some of the objectives of the Nigerian National Communication Policy with regard to the print, radio and television have been implemented, others such as the establishment of Production Fund, establishment of viewing centers, reduction of broadcast license fees and granting of incentives on imported newspaper printing materials and broadcast equipment have yet to be implemented. Effort should be accelerated to actualize this. There is the need to re-jig and replicate the implementation strategies across the three levels of government- federal, state, and local. This would require massive sensitization and involvement of the state and local governments. It would also demand the setting up of NNCP offices at those levels of governance to help mobilise the rural people, and 
actively engage them in the decisions that affect their life positively, and ensure the success of development programme in their respective communities. The media need to play their own part by focusing more attention on rural communities and poverty reduction reporting. The issue of broadcast license fees should be looked into to determine whether to drastically reduce it or scrap it to make it an incentive. The local people who are already financially incapacitated cannot fund community broadcasting unless they are supported directly through parliamentary budgeting.

\section{References:}

1. Adekoya, H.O., and Ajilore, K. (2012). Empowering national development in Nigeria through appropriate national communication policy. Singaporean Journal of Business Economics, and Management Studies, 1(4)

2. Anaeto, S.G. and Anaeto, M. (2010). Development communication: principles and practice. Ibadan: Stirling-Horden Publishers Ltd.

3. Anaeto, S.G, Onabajo, O.S and Osifeso, J.B (2008). Models and theories of communication. African Renaissance Books Incorporated. Bowie: Maryland

4. Blackburn, J. (2000). Understanding Paulo Freire: Reflections on the origins, concepts, and possible pitfalls of his educational approach. Community Development Journal, 35(1), 3-15.

5. Daily Post Newspaper. (2018). Nigeria bi-annual economic update: Fragile recovery. March 5.

6. Diouf, J. (1993). In Fraser, C. and Villet, J. (1993). Communication for development: The role of communication: http://www.fao.org/docrep/t1815e/t1815e02.htm Accessed July 20, 2018.

7. Ekwo, U. (1996). "Commercialisation of news in the Nigerian media: An impediment to information flow". In: I. E. Nwosu and U. Ekwo (Eds.). Mass media \& marketing communications: Principles, perspectives and practice. Enugu: Thought Communications Publishers.

8. Folarin, B.A (1989). Theories of mass communication: An introductory text. Ibadan, Stirling-Horden Ltd.

9. Freedom House. (2011). Nigeria Signs freedom of information bill into law.

10. Gadzekpo, A. (1997). Communication Policies in Civilian and Military Regimes: The Case of Ghana. African Media Review, 11(2). African Council for Communication Education.

11. Greater Hume Shire Council. (2015). Communication strategy and implementation

plan. 
http://www.greaterhume.nsw.gov.au/LinkClick.aspx?fileticket=mAH 91mMgd_Q\%3D\&tabid=114 Accessed August 30, 2018.

12. Harande,Y.I (2009). Library philosophy and practice. http:/www.webpages.uidaho.edu/ mbolin/har,,,,m Accessed July 27, 2018.

13. Johnson, J., and Alao, D. (2013). Towards a robust communication policy in Nigeria: A discourse analysis. Journal of Research and Development. 1(2).

14. Johnson, J. and Alao, D. (2013). Towards a robust communication policy in Nigeria: A discourse analysis. Journal of Research and Development, 1(2)

15. McQuail, D. (2000). Mass communication theory: An introduction, London, Sage Publication.

16. McQuail, D. (1987). Mass communication theory: An introduction (2nd ed.). Thousand Oaks, CA, US: Sage Publications, Inc.

17. Michael, E.J, and Kayode, O.J. (2014). Nigeria's communication policy and news determination. Journal of Law, Policy and Globalisation, 23.

18. Moemeka, A.A. (2012). Development communication in action. Building understanding and creating participation. Abraka: Journal of Communication and Media Research.

19. Naomi O (1995). Towards an integrated view of human rights. Hunger teach net, 6(3): 6-7.

20. National Broadcasting Commission review of the $5^{\text {th }}$ edition of the broadcasting code: call for http://www.nbc.gov.ng/uploads/nbc_documents/1466685527code\%2 0third\%20edition.pdf Accessed August 29, 2018.

21. Nigerian National Communication Policy, 2010. (Reviewed). Federal Ministry of Information, 4-16. Nigerian Mass Communication Policy, 1987. FGP 1345/790/2,000.

22. Nigerian president signs freedom of information bill. June 3, 2011. http://www.freedominfo.org/2011/06/nigerian-president-signsfreedom-of-information-bill/ Accessed August 29, 2018.

23. Ogundele, O. (2018). Good governance and national development. Posted online: March 28, 2018 FacebookTwitterGoogle+PinterestLinkedInWhatsApp

24. Ojo, J. (2016). Communication Policy. https://punch newspaerCOM\%20POLICY\%20JIDE.webarchive. Accessed July 26, 2018.

25. Oladokun, O. (2010). Mass Media Interest and Corruption in Nigeria. Unilag Communication Review. 4(2), August, 24. http://eprints.covenantuniversity.edu.ng/2494/1/Mass\%20Media\%20I 
nterest\%20and\%20Corruption\%20in\%20Nigeria\%20by\%200mojola .pdf. Accessed August 27, 2018.

26. Omojola, O. (2010). Mass media interest and corruption in Nigeria. Communication Review, 4(2), 21-39.

27. Paden, J. N. (1986). Ahmadu Bello, Sardauna of Sokoto: Values and leadership in Nigeria. Zaria: Hudahuda Publishing Co.

28. Rosengren, K. (2000). Communication: An introduction to mass communication. New York, Longman.

29. Sobowale, I. (1989).'Role of national communication policy and communication system in development process of Nigeria" In Akinfeleye, R. (ed.) (2008). Contemporary issues in mass media for development and national security. Lagos: Malthouse.

30. The Punch Newspaper. (2018). NBC kicks over N4.3bn owed by broadcast stations. August 31, p.40.

31. The World Bank. (2015). Nigeria's first community radio hits the airwaves.

http://www.worldbank.org/en/news/feature/2015/09/29/makinghistory-nigerias-first-community-radio-station-hits-the-airwaves Accessed August 18, 2018.

32. Pate, U., Akinfeleye, R. and Oso, L. in Ojo, J. (2016). Imperative of a new Nigerian national communication policy. The Punch Newspaper. October, 26.

33. PM News. (2011). 402 radio, TV licensed in Nigeria. https://www.pmnewsnigeria.com/2012/08/23/402-radio-tv-stationslicensed-in-nigeria/Accessed August 27, 2018.

34. Sarikakis, K. (2004). Media and communications policy: A definition. http://ics.leeds.ac.uk/papers/vp01.cfm? outfit $=\mathrm{ks} \&$ folder $=4 \&$ paper $=25$.

35. TheWorldBankhttps://siteresources.worldbank.org/INTAFRREGTO PTEIA/Resources/mosaica_10_steps.pdf

36. Thirlwall, A.P (2003). Growth and development with special reference to developing economy. New York, Palgrave Macmillan.

37. UNESCO, (1972). Report of the meeting of experts on communication policies and planning. Paris.

38. United Nations Development Programme. (1994). Communication: a key to human development. http:/COMMUNICATION\%20FOR\%20DEV.webarchive Accessed July 24, 2018.

39. United Nations Development Programme. (1993). Human development report: People's participation. http://hdr.undp.org/en/reports/global/hdr1993. Accessed August 30, 
2018.

40. Uwom, O. and Alao, D. (2013). Analysis of media policies in Nigeria and Ghana. Arabian Journal of Business and Management Review (OMAN Chapter). 2(8) 